\title{
H.D. Haustein
}

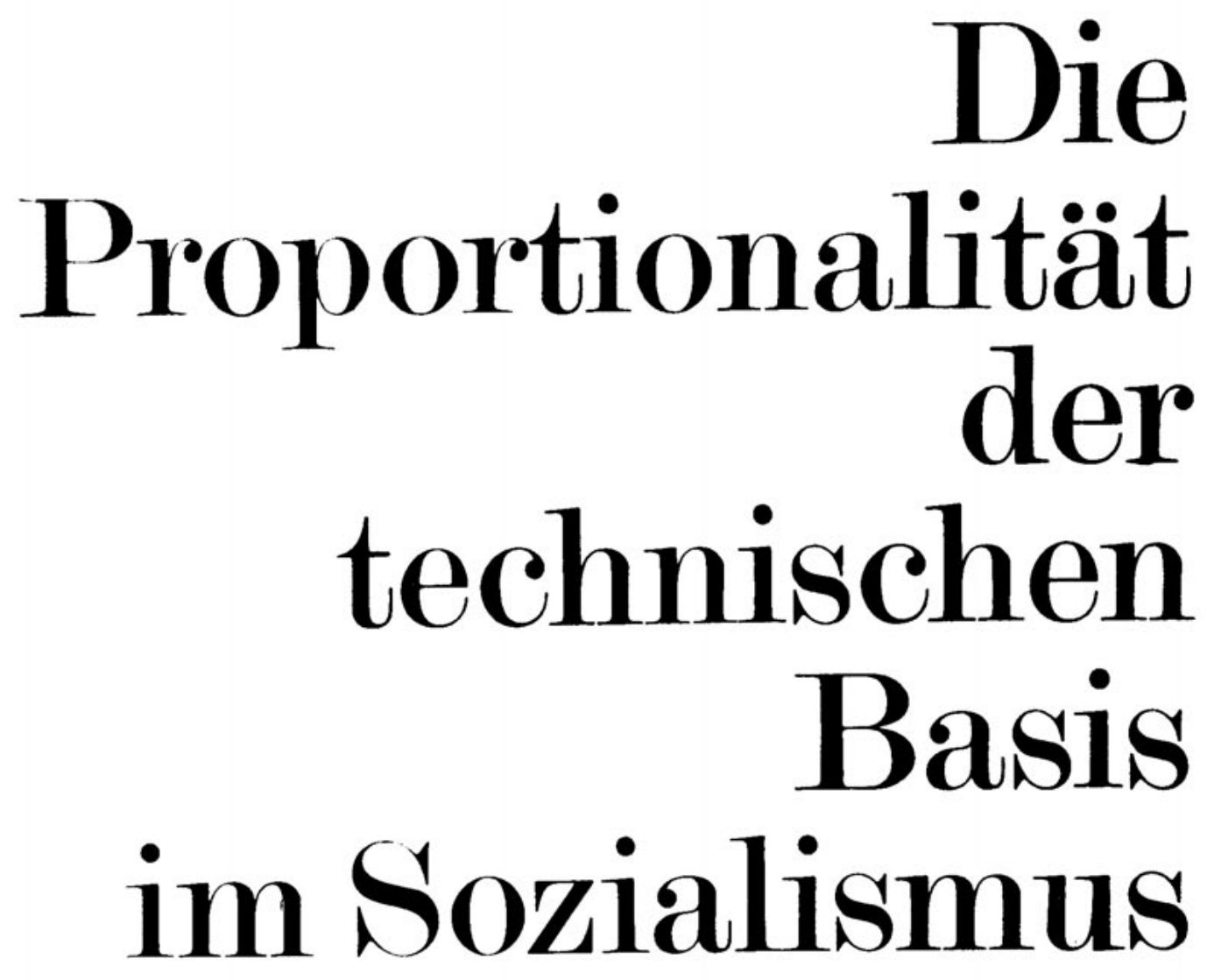

Akademie-Verlag $\cdot$ Berlin 
